\title{
How Much Should I Record During a CEUS Examination? Practical Aspects of the "Real-Time" Feature of a Contrast Ultrasound Study
}

\author{
Wie viel sollte ich während einer CEUS-Untersuchung aufnehmen? Praktische Aspekte \\ der „Echtzeit“-Funktion einer Kontrastmittel-Ultraschalluntersuchung
}

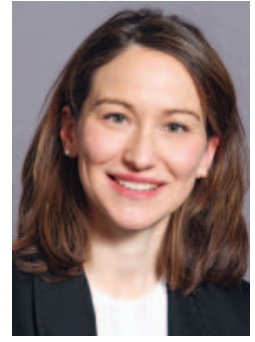

Annamaria Deganello



Maria E. Sellars

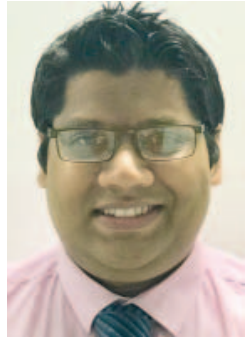

Gibran T. Yusuf



Paul S. Sidhu
Correspondence

Paul S. Sidhu

Department of Radiology, King's College Hospital, Denmark Hill, London SE5 9RS, United Kingdom paulsidhu@nhs.net
Bibliography

DOI https://doi.org/10.1055/a-0717-9582

Published online: 2018

Ultraschall in Med 2018; 39: 484-486

(c) Georg Thieme Verlag KG, Stuttgart · New York

ISSN 0172-4614
The application of microbubble contrast agents to the ultrasound examination over the last 20 years has revolutionised the assessment of focal liver lesions [1], has been applied to many other organs in the body [2, 3] and is now an established adult application, with the use in paediatric patients increasing [4]. The technique is safe and repeatable $[5,6]$. A contrast-enhance ultrasound (CEUS) examination generates a substantial amount of data for storage with the use of continuous recording, so much so that in Departments of Radiology, where a Picture Archiving System (PACS) stores data for a considerable number of imaging examinations, rumblings of discontent from the PACS manager can be heard. The misconception that the "video-clips" from a CEUS occupy too much storage is a fallacy, as many whole body computed tomography (CT) examinations from a trauma patient, with reconstruction in thin slices and 3-D, can occupy a large amount of storage space. The perception is that the "new-boy on the block" will clog up the PACS with superfluous images; perhaps better to make room for other imaging modalities.

There is no battle to be fought here; we can help ourselves. There is perhaps no real need to take long and extensive real time "video-clips" of the entire CEUS examination, but to record only the most informative sections. This is not a new concept, and it is worthwhile revisiting the background to extensive image storage as there are very good technical reasons not to perform a continuous recording, making the CEUS examination recording shorter and even more useful [7].
Characterisation of focal liver lesions with CEUS represents the single most important application of CEUS with numerous studies confirming the accuracy of this technique in comparison with $\mathrm{CT}$, and near ability to match Magnetic Resonance (MR) imaging [8, 9]. The arterial phase and the late portal venous phase are crucial to the assessment for characterisation; the washout particularly important with hepatocellular carcinoma, which may be delayed as opposed to metastatic lesions where washout is relatively early [10]. With a focal liver lesion, the arterial pattern, particularly in the benign lesion is paramount to the interpretation, but this phase lasts only for 30 to 40 seconds at most, and is nearly always informative by 20 to 30 seconds [11]. The washout phase starts early for the metastatic lesion, often before 60 seconds and will continue to wash-out for the rest of the examination. A hepatocellular carcinoma will washout slowly and may not demonstrate this washout for 180 seconds or more, depending on the cell differentiation. A most unlikely scenario is that a lesion that washes out then reaccumulates contrast and enhances over time; in-filling of a benign haemangioma is an exception where the characteristic globular in-filling is diagnostic.

The essence of this is twofold; it is unlikely that extending the "video-clip" beyond 60 seconds will capture any further relevant information, and recording of washout is a prolonged effort, not needing continuous image storage. More important is the potential for microbubble "destruction" with prolonged, intense scanning over one area, with near field lesions most vulnerable, resulting in "pseudo-washout" $[12,13]$. In short, continuous scanning for the first 60 seconds and then intermittent scanning after 
60 seconds, taking an image on average every 30 - 60 seconds for the duration of the remainder of the examination will probably suffice. The most comfortable manner in which to perform the intermittent scanning is by "freezing" the image, keeping the transducer in the fixed appropriate position for the lesion under investigation, and re-imaging for a short period to store a single representative image - the "snapshot".

This will be entirely different for imaging of organs without the dual blood supply of the liver, and where characterisation is less vital. The need for a prolonged "video-recording" is less imperative in many scenarios; in the kidney the abnormal vascular pattern is seen in the early arterial phase, with washout evident quite soon after, and the pyramids enhancing approximately 30 - 40 seconds after the cortex. The continuous recording need not be more than 40 seconds, followed by the intermittent single image acquisition. This application would also suffice for the pancreas or spleen, with the bowel perhaps more reliant on the increased enhancement in the arterial phase alone. When used a s a problem solving tool, in intracavitary use [14] or as part of an interventional procedure [15], short "video-clips" or just representative images is all that is required.

The acquisition of a "video-clip" should always be supplemented by representative single images of the particular diagnostic appearance e.g. the "spoke-wheel" in the arterial phase of a focal nodular hyperplasia or the "globular" peripheral lesion pattern of a haemangioma. Often during the review of the "video-clip" these representative images are saved, ready to be presented at the multi-disciplinary meetings where the case is discussed; nobody will want to sit through all the "video-clips" of your examination! Herein lies a problem, all manufacturers bar one does not allow you to obtain a single representative image during acquisition whilst the video is being recorded, which if acquired halts the video recording. This seems only to impart a restriction that delays patient flow and ease of the examination, if the operator has to review the "video-clip" after every patient. Although good practice to review the recording for any "missed" features, the ability to take an image during the dynamic phase is always rewarding; you capture the moment!

In essence, there is no need to record a full 4-5 minutes of a CEUS examination, a continuous recording for the first 60 seconds will suffice with single images when needed for the later phases, ostensibly looking for any form of washout pointing to potential malignancy in the liver, and elsewhere. This will reduce pressure on the storage of images on your PACS, helping to maintain a good working relationship with the PACS manager. More importantly, this practice will reduce the potential of accelerated microbubble destruction, particularly in the near-field lesion and ensure a long-lasting examination.

\section{Wie viel sollte ich während einer CEUS- Untersuchung aufnehmen? Praktische Aspekte der „Echtzeit“-Funktion einer Kontrastmittel-Ultraschalluntersuchung}

Die Anwendung von Mikrobubble-Kontrastmitteln bei Ultraschalluntersuchungen hat die Beurteilung von fokalen Leberläsionen in den letzten 20 Jahren revolutioniert [1]. Sie fand auch bei vielen anderen Körperorganen Anwendung [2, 3] und ist heute bei der Untersuchung Erwachsener und in zunehmendem Maße bei pädiatrischen Patienten [4] etabliert. Die Technik ist sicher und wiederholbar [5, 6]. Eine kontrastverstärkte Ultraschalluntersuchung (CEUS) erzeugt bei kontinuierlicher Aufzeichnung eine beträchtliche zu speichernde Datenmenge, die in Anbetracht der beachtlichen Zahl an bildgebenden Untersuchungen in den Bildarchivierungssystemen (PACS) der radiologischen Abteilungen für eine gewisse Unzufriedenheit bei den PACS-Managern sorgt. Der Irrglaube, dass die Videoclips eines CEUS zu viel Speicher belegen, ist falsch. So können viele Ganzkörper-Computertomografien (CT) eines Traumapatienten mit Rekonstruktion in dünnen Schicht- und 3-D-Bildern auch sehr viel Speicherplatz belegen. Die Vorstellung, dass der „Neuling“ das PACS mit unnötigen Bildern verstopfen wird; ist vielleicht eher dem Wunsch geschuldet, mehr Platz für andere bildgebende Verfahren zu schaffen.

Hier müssen keine Kämpfe ausgetragen werden, wir können wir bei uns selbst beginnen. Denn es ist vielleicht nicht wirklich notwendig, lange und umfangreiche Echtzeit-Videoclips der gesamten CEUS-Untersuchung zu erstellen, sondern nur die informativsten Abschnitte aufzunehmen. Dies ist kein neuer Gedanke und es lohnt sich, die Hintergründe für eine umfangreiche Bildspeicherung zu überdenken, denn es gibt sehr gute technische Begründungen keine kontinuierliche CEUS-Aufzeichnung durchzuführen, wodurch diese kürzer und noch nützlicher wird [7].

Die Charakterisierung von fokalen Leberläsionen stellt die absolut wichtigste CEUS- Anwendung dar, wobei zahlreiche Studien die Treffsicherheit dieser Technik im Vergleich zur CT- und Magnetresonanz (MR)- Bildgebung bestätigen [8, 9]. Die arterielle Phase und die späte portalvenöse Phase sind entscheidend für die Beurteilung der Charakteristik. Insbesondere das Washout ist bei mhepatozellulären Karzinom besonders wichtig, da es im Gegensatz zu metastatischen Läsionen bei denen das Washout relativ früh ist, verzögert sein kann [10]. Bei einer fokalen Leberläsion steht das arterielle Muster, insbesondere bei benigner Läsion, im Vordergrund, aber diese Phase dauert nur höchstens 30 bis 40 Sekunden und ist fast ausschließlich nur 20 bis 30 Sekunden lang informativ [11]. Die Washout-Phase bei einer metastatischen Läsion beginnt früh, oft vor 60 Sekunden und dauert für den Rest der Untersuchung an. Beim hepatozellulären Karzinom gibt es ein langsames Washout, welches sich abhängig von der Zelldifferenzierung erst nach 180 Sekunden oder mehr zeigen kann. Ein sehr unwahrscheinliches Szenario ist, dass eine Läsion ein Washout statt einer Wiederanflutung aufweist und über einen längeren Zeitraum eine Kontrastaufnahme zeigt. Die Anflutung des gutarti- 
gen Hämangioms ist eine Ausnahme, bei der die charakteristische Anflutung („globular in-filling“) Diagnose stellend ist.

Das lässt einen zweifachen Schluss zu: Es ist unwahrscheinlich, dass die Verlängerung des „Videoclips“ über 60 Sekunden hinaus weitere relevante Informationen erfasst, und die Aufzeichnung des Washouts ist eine zusätzliche Bemühung, die im Hinblick auf eine kontinuierliche Bildspeicherung nicht nötig ist. Wichtiger ist die potentielle Zerstörung von Microbubbles durch längeres, intensives Scannen auf einem Bereich, was zu einem „PseudoWashout" führt, wobei Nahfeldläsionen am anfälligsten sind $[12,13]$. Kurz gesagt, werden wahrscheinlich ein kontinuierliches Scannen für die ersten 60 Sekunden und dann ein intermittierendes Scannen nach 60 Sekunden, wobei ein Bild im Durchschnitt alle 15 Sekunden bis zum Ende der Untersuchung erstellt wird, ausreichen. Die bequemste Art ein intermittierendes Untersuchungsscan durchzuführen, besteht darin das Bild „einzufrieren“, den Schallkopf in der festen geeigneten Position für die zu untersuchende Läsion zu halten und nach kurzer Zeit eine Neuaufnahme durchzuführen, um ein einzelnes repräsentatives Bild den „Schnappschuss“ - zu speichern.

Dies stellt sich für die Bildgebung anderer Organe als der Leber mit ihrer doppelten Blutversorgung völlig anders dar, und hier ist die Charakterisierung auch weniger entscheidend. Die Notwendigkeit einer längeren „Videoaufnahme“ ist bei vielen Anwendungen weniger zwingend erforderlich. In der Niere ist das abnormale vaskuläre Muster in der frühen arteriellen Phase zu sehen, wobei das Washout ziemlich bald danach auftritt und die Kontrastaufnahme der Pyramiden ungefähr 30-40 Sekunden nach dem Kortex erfolgt. Die kontinuierliche Aufzeichnung muss nicht länger als 40 Sekunden dauern, gefolgt von der intermittierenden Einzelbilderfassung. Dieses Vorgehen wäre auch für Pankreas oder Milz ausreichend, wobei man beim Darm vielleicht eher nur auf die erhöhte Kontrastaufnahme in der arteriellen Phase angewiesen ist. Beim Einsatz der Methode zur Problemlösung, bei der intrakavitären Anwendung [14] oder bei einer Intervention [15] sind lediglich kurze „Videoclips“ oder repräsentative Bilder erforderlich.

Die Aufnahme eines „Videoclips“ sollte immer durch repräsentative Einzelbilder des jeweiligen diagnostischen Erscheinungsbildes ergänzt werden, z.B. das „Radspeichenmuster“ in der arteriellen Phase einer fokalen nodulären Hyperplasie oder das "globulare“ periphere Läsionsmuster eines Hämangioms. Oft werden diese repräsentativen Bilder während der Überprüfung des „Videoclips“ gespeichert und können bei multidisziplinären Treffen, bei denen der Fall diskutiert wird, präsentiert werden. Niemand wird alle „Videoclips“ Ihrer Untersuchungen durchgehen wollen! Hierin liegt ein Problem, da alle Gerätehersteller - außer einem einzigen - es nicht ermöglichen, ein repräsentatives Einzelbild während der Videoaufnahme zu machen, ohne dass diese unterbrochen wird. Dies scheint eine Einschränkung darzustellen, die den Patientenfluss verzögert und die Untersuchung erschwert, da der Bediener den „Videoclip“ nach jedem Patienten überprüfen muss. Obwohl ist es eine gute Übung ist, die Aufnahme im Hinblick auf „verpasste“ Merkmale zu überprüfen, ist die Möglichkeit ein Bild während der dynamischen Phase aufzunehmen immer lohnend, denn Sie erfassen den Moment!
Im Wesentlichen besteht keine Notwendigkeit, eine vollständige 4-5-minütige CEUS-Untersuchung aufzuzeichnen. Eine kontinuierliche Aufzeichnung für die ersten 60 Sekunden und wenn nötig einzelne Aufnahmen der späten Phasen reichen aus, wenn man die die Washout-Charakteristika untersucht, die auf eine potentielle Malignität in der Leber und anderswo hinweisen. Das verringert den Druck bezüglich der Bildspeicherung auf Ihrem PACS und trägt zu einer guten Zusammenarbeit mit ihrem PACSManager bei. Noch wichtiger ist, dass durch dieses Vorgehen eine mögliche beschleunigte Zerstörung von Mikrobubbles, insbesondere bei Nahfeldläsionen, verringert wird und eine länger anhaltende Untersuchung gewährleistet ist.

\section{References}

[1] Claudon M, Dietrich CF, Choi BI et al. Guidelines and good clinical practice recommendations for contrast enhanced ultrasound (CEUS) in the liver - update 2012. Ultraschall in Med 2013; 34: 11-29

[2] Sidhu PS, Cantisani V, Dietrich CF et al. The EFSUMB Guidelines and Recommendations for the Clinical Practice of Contrast-Enhanced Ultrasound (CEUS) in Non-Hepatic Applications: Update 2017 (Long Version). Ultraschall in Med 2018; 39: e2-e44

[3] Sidhu PS, Cantisani V, Dietrich CF et al. The EFSUMB Guidelines and Recommendations for the Clinical Practice of Contrast-Enhanced Ultrasound (CEUS) in Non-Hepatic Applications: Update 2017 (Short Version). Ultraschall in Med 2018; 39: 154-180

[4] Sidhu PS, Cantisani V, Deganello A et al. Role of contrast-enhanced ultrasound (CEUS) in paediatric practice: An EFSUMB position statement. Ultraschall in Med 2017; 38: 33-43

[5] Piscaglia F, Bolondi L. The safety of SonoVue in abdominal applications: retrospective analysis of 23188 investigations. Ultrasound in Med Biol 2006; 32: 1369-1375

[6] Yusuf GT, Sellars ME, Deganello A et al. Retrospective Analysis of the Safety and Cost Implications of Pediatric Contrast-Enhanced Ultrasound at a Single Center. Am J Roentgenol 2016; 208: 446-452

[7] Dietrich CF, Averkiou M, Nielsen MB et al. How to perform ContrastEnhanced Ultrasound (CEUS). Ultrasound Int Open 2018; 04: E2 -E15

[8] Seitz K, Bernatik T, Strobel D et al. Contrast-enhanced ultrasound (CEUS) for the characterization of focal liver lesions in clinical practice (DEGUM Multicenter Trial): CEUS vs. MRI - a prospective comparison in 269 patients. Ultraschall in Med 2010; 31: 492-499

[9] Barr RG. Contrast enhanced ultrasound for focal liver lesions: how accurate is it? Abdominal Radiology 2018; 43: 1128-1133

[10] Piscaglia F, Wilson SR, Lyshchik A et al. American College of Radiology Contrast Enhanced Ultrasound Liver Imaging Reporting and Data System (CEUS LI-RADS) for the diagnosis of Hepatocellular Carcinoma: a pictorial essay. Ultraschall in Med 2017; 38: 320-324

[11] Seitz K, Strobel D, Bernatik T et al. Contrast-Enhanced Ultrasound (CEUS) for the Characterization of Focal Liver Lesions Prospective Comparison in Clinical Practice: CEUS vs. CT (DEGUM Multicenter Trial). Ultraschall in Med 2009; 30: 383-389

[12] Dietrich CF, Ignee A, Hocke $M$ et al. Pitfalls and artefacts using contrast enhanced ultrasound. Z Gastroenterol 2011; 49: 350-356

[13] Fetzer DT, Rafailidis V, Peterson C et al. Artifacts in contrast-enhanced ultrasound: a pictorial essay. Abdominal Radiology 2018; 43: 977-997

[14] Yusuf GT, Fang C, Huang DY et al. Endocavitary contrast enhanced ultrasound (CEUS): a novel problem solving technique. Insights Imaging 2018; 9: 303-311

[15] Huang DY, Yusuf GT, Daneshi M et al. Contrast-enhanced US guided Interventions: Improving Success Rate and Avoiding Complications Using US Contrast Agents. Radiographics 2016; 37: 652-664 